NBER WORKING PAPER SERIES

\title{
INVENTIVE ACTIVITY AND THE MARKET FOR TECHNOLOGY IN THE UNITED STATES, 1840-1920
}

\author{
Naomi R. Lamoreaux \\ Kenneth L. Sokoloff \\ Working Paper 7107 \\ http://www.nber.org/papers/w7107 \\ NATIONAL BUREAU OF ECONOMIC RESEARCH \\ 1050 Massachusetts Avenue \\ Cambridge, MA 02138 \\ May 1999
}

The views expressed herein are those of the authors and do not necessarily reflect the views of the National Bureau of Economic Research.

(0) 1999 by Naomi R. Lamoreaux and Kenneth L. Sokoloff. All rights reserved. Short sections of text, not to exceed two paragraphs, may be quoted without explicit permission provided that full credit, including (1) notice, is given to the source. 
Inventive Activity and the Market for

Technology in the United States, 1840-1920

Naomi R. Lamoreaux and Kenneth L. Sokoloff

NBER Working Paper No. 7107

May 1999

\section{ABSTRACT}

The growth of the U.S. economy over the nineteenth century was characterized by a sharp acceleration in the rate of inventive activity and a dramatic rise in the relative importance of highly specialized inventors as generators of new technological knowledge. Relying on evidence compiled from patent records, we argue that the evolution of a market for technology played a central role in these developments. Across both individuals and geographic areas, the expansion of opportunities to trade in patent rights was closely associated with increases in specialization at invention, as well as advances in rates of invention more generally. The patent system is often celebrated for the stimulus to invention provided by granting limited monopoly rights to inventors for the use of their discoveries, but its specification of tradable assets in technology has also been important.

Naomi R. Lamoreaux

Departments of Economics and History University of California, Los Angeles Los Angeles, CA 90095-1477 and NBER lamoreaux@econ.ucla.edu
Kenneth L. Sokoloff Department of Economics University of California, Los Angeles Los Angeles, CA 90095-1477 and NBER sokoloff@ucla.edu 
One of the fundamental processes of economic development is the evolution of ever more articulated markets that lower transactions costs, permit commodities to be traded over longer distances, and encourage greater specialization by productive resources. The importance of the phenomenon is evident in the extensive attention economists have long devoted to the changes in the operation and structure of markets for labor, capital, and products over time. There has to date, however, been only limited examination of the market for technology. Given the significance for economic growth of the generation of new technologies, and the recognition that inventive activity is not unlike other investments in being responsive to material returns, systematic investigation of how trade in technological information has been carried out is long overdue. Although the reasons for this neglect are not entirely clear, the study of the market for technology has perhaps been inhibited by notions that problems of asymmetric information make contracting for technology in the market very difficult and costly, and that there are substantial advantages to inventive activity being conducted within the same firms that would commercially exploit the new knowledge. These largely theoretical conceptions may have encouraged the impression that the scope for market exchange of technological information is quite narrow.

Although the idea that new technologies are typically produced within those firms that commercially exploit the discoveries may seem very reasonable in a context where large-scale R \& D laboratories are common, this condition has not always held. The United States economy was characterized by high rates of invention and technological change over most of the nineteenth century - well before the widespread organization of 
these sorts of in-house facilities. ${ }^{\prime}$ One indicator of this is the record of patenting, which began to grow very rapidly soon after the major reform of the patent law in 1836 . Per capita rates more than doubled during the $1840 \mathrm{~s}$, the $1850 \mathrm{~s}$, as well as during the $1860 \mathrm{~s}$. From fewer than 30 patents per million residents of the United States per year during the 1840 s, the rate rose to over 300 by the early 1870 s, and peaked just above 360 in the early 1890s (see Table 1). ${ }^{2}$ Among the tens of thousands of patents granted over the nineteenth and early twentieth century period were those of Cyrus McCormick, who obtained patents for a reaper and other farm equipment; Gail Borden, who obtained patents for the concentrating and preserving of milk and other foods; Thomas Edison, who obtained patents for the incandescent light bulb, the phonograph, and motion pictures; Alexander Graham Bell, who patented the telephone; the Wright Brothers, who flew the first airplane; Nicholas Tesla, who worked out a system for transmitting electric power; and Lee de Forest, Reginald Fessenden, and others, who developed the technology for radio.

Despite the obvious importance of many of the new technologies discovered, scholars have seldom asked whether this enormous wave of creativity is consistent with the conventional paradigm of where significant inventions emanate from, or sought to

\footnotetext{
${ }^{1}$ For an overview of the growth of in-house R\&D, see David C. Mowery, "Industrial Research and Firm Size, Survival, and Growth in American Manufacturing, 1921-1946: An Assessment," Journal of Economic History, 43 (Dec. 1983), pp. 953-80; and Mowery and Nathan Rosenberg, Technology and the Pursuit of Economic Growth (New York: Cambridge University Press, 1989), pp. 35-97. For specific examples, see Margaret B. W. Graham and Bettye H. Pruitt, $R \& D$ for Industry: A Century of Technical Innovation at Alcoa (New York: Cambridge University Press, 1990); David A. Hounshell and John Kenly Smith, Jr., Science and Corporate Strategy: Du Pont R\&D, 1902-1980 (New York: Cambridge University Press, 1988); Leonard S. Reich, The Making of American Industrial Research: Science and Business at GE and Bell, 1876-1926 (New York: Cambridge University Press, 1985); and George Wise, Willis R. Whitney, General Electric, and the Origins of U.S. Industrial Research (New York: Columbia University Press, 1985).

${ }_{2}^{2}$ Although the patenting rate has occasionally blipped up to surpass the peak of the early 1890 s, this ceiling has essentially endured until very recently.

${ }^{3}$ See Thomas P. Hughes, American Genesis: A Century of Invention and Technological Enthusiasm, 1870-1970 (New York: Penguin, 1989), pp. 13-52.
} 
identify the conditions that made this period such a productive one for independent inventors. Rather they have preferred to highlight developments that were unlikely to have been major factors until the twentieth century: the rise of large-scale business organizations and their founding of the in-house $\mathrm{R} \& \mathrm{D}$ laboratories in particular. In contrast, our focus is on the evolution of institutions over the nineteenth century that made it easier to trade in the rights to patented inventions - essentially a market for patented technologies. There is, in our view, good reason to believe that it was the expanded opportunities to trade in the rights to patented technologies that enabled the independent inventors of this golden age to flourish, and that stimulated the growth of inventive activity more generally. Early nineteenth-century inventors generally took personal responsibility for the commercial development of their ideas, making it difficult for them to focus exclusively on the generation of new technologies. ${ }^{4}$ As institutions emerged to facilitate the sale or transfer of patent rights to other individuals or firms better positioned to commercially exploit them, however, many inventors increasingly took advantage of this avenue for extracting the returns to their efforts and concentrated on inventive activity. In other words, the growth of market trade in patents raised the returns to invention generally, and encouraged a division of labor whereby technologically creative individuals increasingly specialized in their comparative advantage -- invention.

We argue that the patent system was central to the evolution of this market for technology, and suggest that the stimulus to invention provided by the patent system through its facilitation of trade in patented technological information has not always been

\footnotetext{
${ }^{4}$ See B. Zorina Khan and Kenneth L. Sokoloff, "'Schemes of Practical Utility': Entrepreneurship and Innovation Among 'Great Inventors' in the United States, 1790-1865," Journal of Economic History, 53 (June 1993), pp. 289-307.
} 
fully appreciated. Throughout the paper, we employ patent records to explore and establish the empirical association over the nineteenth century between the opportunities to trade patent rights and both specialization at invention by individuals and levels of inventive activity more generally. In addition to this quantitative evidence, we also draw on anecdotal information, including archival records of patent lawyers, to illustrate some of the mechanisms through which trade in patented technology was conducted. It is evident that patent agents and lawyers often performed the functions of intermediaries in the market for technology, matching inventors seeking to sell new technological ideas with buyers eager to develop, commercialize, or invest in them. As we note, the local character of this sort of trade in technological information may shed light on the persistence of some geographic differentials in invention. Patent agents, attorneys, and other intermediaries in this market concentrated first in areas or regions where inventive activity had been high, such as in the Northeast and urban centers generally, and this may have contributed to a self-reinforcing process or cycle whereby the early clustering of patenting activity encouraged investments supporting a market for technology (such as the establishment of patent agencies), which in turn stimulated greater specialization and productivity in invention, and so on.

We also use a sample drawn from the Patent Office's manuscript records of patent sales to examine more directly the emergence of intermediaries who were relatively specialized in this market for technology, and the characteristics of those inventors who dealt with such agents. The findings that the more specialized inventors tended disproportionately to deal with the more specialized intermediaries, and vice versa, are consistent with our view that the growth of the market for technology and higher levels of 
invention, and especially specialization at invention, were mutually reinforcing and developed together. It is well known that, in the case of financial markets, the development of intermediaries not only solved the information problems associated with matching those seeking investment capital with whose who had savings, but also raised the levels of savings and investment in the economy. Our goal is to assess the extent to which the emergence of intermediaries in the market for technology had the analogous effect of boosting rates of invention and technological change.

The U.S. patent system was created in accordance with the Commerce Clause of the Constitution "to promote the progress of science and useful arts by securing to authors and inventors the exclusive right to their respective writings and discoveries," and it provided the institutional framework within which trade in technology evolved over the course of the nineteenth century. ${ }^{5}$ Although similar in general structure to that in Britain, the U.S. laws made a few salient innovations, which seem consciously directed at stimulating inventive activity - and thus technological progress. Among them were much lower registration fees, impersonal administrative procedures for handling applications, and the reservation for only the "first and true" inventor an exclusive property right to the new technology for a fixed term of years. These provisions extended the incentive of property rights to a broad range of inventors and inventions, and meant that inventors could reveal information about their devices and still be protected against the possibility that someone else would directly exploit their ideas without compensation. Another

\footnotetext{
${ }^{5}$ United States Constitution, Article 1, section 8, clause 8.
} 
important feature of the law was the requirement that patentees be individual men or women; firms could not receive patents directly for inventions developed in their shops. These individual patentees then had the option of exploiting their property rights themselves, or they could sell (assign) or lease (license) them to others, whether individuals or firms. Of course, the ability of patentees to find buyers or licensees for their patents depended on the security of these property rights. Responsibility for enforcing patent rights was left to the federal courts, and judges quickly evolved an effective set of principles for protecting the rights of patentees and also of those who purchased or licensed patented technologies. As a result, not only did thousands of inventors pay rather substantial fees to obtain patents, but large numbers of individuals and firms paid even greater amounts to purchase or license patent rights. ${ }^{6}$

Although one purpose of the patent system was to stimulate invention by granting creative individuals secure rights to their intellectual property, another was to promote the diffusion of technological knowledge. One way in which the law stimulated such diffusion was through public disclosure; all patentees were required to provide the Patent Office with detailed specifications for their inventions, and the result was a central storehouse of technological information that was open to all. Anyone could research others' inventions in the Patent Office files, and more convenient means of tapping this resource were soon developed. The Patent Office itself published periodic lists of patents awarded, and private journals, many of them owned by the leading patent agencies of the day, emerged

\footnotetext{
${ }^{6}$ See B. Zorina Khan and Kenneth L. Sokoloff, "Patent Inst itutions, Industrial Organization and Early Technological Change: Britain and the United States, 1790-1850," in Technological Revolutions in Europe: Historical Perspectives, ed. Maxine Berg and Kristine Bruland (Cheltenham, UK: Edward Elgar, 1998); and Khan, "Property Rights and Patent Litigation in Early Nineteenth-Century America," Journal of Economic History, 55 (Mar. 1995), pp. 58-97.
} 
to improve upon this service. One of the most important was Scientific American, established in the 1840s and published by Munn and Company, the largest patent agency of the nineteenth century. Others included the American Artisan, published by Brown, Coombs \& Company; the American Inventor, by the American Patent Agency; and the Patent Rights Gazette, by the United States Patent Right Association (which, despite its name, functioned as a general patent agency). Serving national readerships, these journals featured articles about major technological improvements, printed complete lists of patents issued (often on a weekly basis), and offered to provide readers with copies of full patent specifications for a small fee. They also included a variety of advertisements that disseminated information about inventions (or how to profit from them), placed by patent agents and lawyers soliciting clients, detective agencies specializing in patent issues, inventors seeking partners with capital to invest, patentees hoping to sell or license rights to their technologies, and producers of patented products trying to increase their sales. ${ }^{7}$

Of course this intense interest by a broad spectrum of private parties in patented or patentable inventions (and their marketing) reflects a fundamental, if indirect, way in which the framers of the patent system sought to improve the spread of technology. From the very first patent law of 1790 , there was explicit provision for the sale of patent rights, and both the courts and the U.S. Patent Office acted to facilitate such transfers. In doing so, the patent system not only increased the potential return to patentees, but also encouraged the flow of the new technological information to those positioned to put it to

\footnotetext{
${ }^{7}$ Over time, specialized trade journals also emerged in industry after industry to keep producers informed about patents of interest. The Journal of the Society of Glass Technology, for example, provided detailed descriptions of all patents taken out in the United States and Britain that were relevant to the manufacture of glass. For discussion of patterns of inventive activity and technological change in this
} 
best use. The market for technology was to work in a manner not unlike those for other valuable assets with specified and tradable property rights.

Although patenting activity had been increasing beforehand, the pace of growth appears to have accelerated markedly in the decades following the Patent Act of $1836 .^{8}$ With this law, the U.S. adopted the examination system in use today, whereby each application is scrutinized by technical trained examiners to ensure that the invention constituted an original advance in the state of the art, and is otherwise deserving of a patent. This toughening of the requirements led to an immediate decrease in the numbers granted, but the change in the system had been intended to facilitate the enforcement of legitimate property rights in technology by decreasing uncertainty about how the validity of a patent would stand up in court. One would expect such a change to be a net stimulus to patenting and trade in patent rights over the long run, and as suggested by the figures in Table 1 , the most dramatic increases in the rate of patenting per capita in the history of the U.S. followed shortly afterward -- rising more than ten times from 1840 through 1870. Not coincidentally, the numbers of patent agents and attorneys also began to mushroom in the late 1830 s and 1840 s, first in the vicinity of Washington and then in Boston and other cities of the Northeast where patenting rates were high. ${ }^{9}$ At first the primary function of patent agents and lawyers was to shepherd applications for patents

industry, see Lamoreaux and Sokoloff, "Location and Technological Change in the American Glass Industry During the late Nineteenth and Early Twentieth Centuries," unpublished manuscript, 1998.

${ }^{8}$ For a discussion of early-nineteenth century growth in rates of patenting, see Sokoloff, "Inventive Activity in Early Industrial America: Evidence from Patent Records, 1790-1846," Journal of Economic History, 48 (Dec. 1988), pp. 813-50.

${ }^{9}$ Some of the largest of these firms maintained offices in several cities, but others often linked themselves together through chains of correspondent relations (similar to those that characterized the banking system at the same time), providing their local clients with access to agents in Washington who were perhaps more specialized in their knowledge and/or could directly exploit the information in Patent 
through the official review process and to defend previously issued patents in interference and infringement proceedings, but as time went on they increasingly took on other roles in the market for technology, including serving as intermediaries in the sale of patents.

The reasons patentees had for selling off all or a share of the rights to their discovery varied with their circumstances. At first (prior to the emergence of a national product market), most sales of patents involved separate transfers to firms in different geographic markets, allowing inventors to extract returns over and above those they earned through direct commercial development in their home districts. Others gave shares to partners who provided capital to support the underlying inventive activity or the commercial development of the invention. Finally, many sold off their full rights to assignees who were better positioned to develop the new technology commercially. What is common to all of these forms of assignment was that the ability to trade property rights in technological information, based on the patent law and other institutions contributing to this market, encouraged greater specialization at inventive activity by the inventor.

The destruction by fire of the building housing the Patent Office, also in 1836, prevents us from studying the sales (assignments) of patents prior to the change in the law enacted in that year. What is apparent from the surviving records, dating back to 1837 , however, is that within a few years trade in patent rights attained a high volume relative to the numbers of inventions patented, and that the bulk of this early commerce in patented technologies involved attempts to obtain returns from inventions across a range of geographically distinct markets. During the 1840 s, there were many patent assignments filed with the Patent Office for each patent granted (3 to 6 times as many by our

Office files, as well as to information on conditions relevant to patenting and the market for technology 
estimates), while 80 to 90 percent of the assignments registered with the Patent Office were "geographic". The predominance of such assignments declined (below 30 percent by the 1870s) as improvements in transportation extended the geographic extent of product markets, and the ratio of assignments to patents correspondingly decreased, but the total volume of trade - as indicated by the number of assignment contracts filed with the Patent Office - grew rapidly over time. ${ }^{10}$ It is clear that an extensive market in patent rights evolved alongside, if not together with, the dramatic increase in per capita patenting rates that took place during the middle third of the nineteenth century.

As is evident from Table 2, which is based on our work with a sample of assignment contracts from 1871, 1891, and 1911, the ratio of assignments to patents awarded continued in a declining trend -- to 0.83 in 1870-71, and 0.71 in 1890-91 and 1910-11. Much of this decrease was due to the diminishing importance of geographic assignments, but another factor was the shift over time toward greater use of licensing of patents in lieu of secondary assignments. Since licensing contracts were not typically registered with the Patent Office, we suspect that a more comprehensive measure of trade in rights to patented technologies would reveal an increase over time (rather than a decrease) in the volume of trade in patent rights relative to the numbers of patents (or the stock of technological knowledge under patent protection). ${ }^{11}$ The fall over time in the

more generally throughout the country.

${ }^{10} \mathrm{We}$ benefit here from the legal requirement that all patent assignments had to be filed with the Patent Office within three months in order to be legally binding. These characterizations and estimates are based on the counts of the total number of assignments, and of various types of assignments, appearing in the Digests for inventions patented by inventors whose last name began with the letter ' $B$ '. They were calculated from the assignments filed during January, February, and March of $1844,1848,1852,1855$, 1862,1866 , and 1874 .

${ }^{11}$ These ratios are not measures of the proportion of patents that were ever assigned, which we cannot reliably calculate, but instead are estimates of the volume of assignment activity relative to 
relative frequency of assignments that were secondary is consistent with this interpretation. Another secular trend manifested throughout the country was the dramatic decline in the proportion of assignments that took place after issue, from 72.3 percent of those concerned with patents granted to residents of the U.S in $1870-71$, to 36.5 percent. in 1910-11. The patterns suggest that as the market for technology developed, patent assignments were arranged earlier (relative to the date the patent was awarded), more likely to transfer rights for the entire U.S., and less likely to be secondary (have assignors other than the patentee). ${ }^{12}$

A salient feature of the patterns of patent assignment presented in Table 2 is that the regions with the highest ratios of assignments to patents (reported as an index, with the national average set to 100 in each year) - New England, the Middle Atlantic, and East North Central -- are also those that had long exhibited the highest rates of patenting per capita (see Table 1) as well as the largest proportions of patents assigned at issue (Table 3). The results indicate, accordingly, that these regions had especially extensive trade in patent rights on a per capita (as well as a per patent) basis, and that high rates of patenting and trade in patented technologies tended to develop together. The variation across regions in how quickly patent assignments occurred also points to a more rapid development of intermediation between buyers and sellers of patents in the regions with higher rates of patenting per capita.

patenting activity. One cannot, accordingly, infer from the fall in these ratios that the proportion of patents ever assigned also declined after 1870-71.

${ }^{12}$ Part, but not all, of the decline in the proportion of assignments that occurred after issue was due to the decrease in the prevalence of secondary assignments and to the longer periods of time between the application for, and the granting of, a patent. 
Table 3 reports the proportion of patents in the cross-sectional samples that were assigned at issue, as well as the frequency of various types of assignments, including those going to companies. These data, drawn from the Annual Reports of the Commissioner of Patents, are not as rich as the sample of assignment contracts in that they do not capture information on assignments made after the issuance of the patent, but they are useful in gauging what happened with a random set of patents. Both the total proportion of patents assigned at issue and the fraction of assignments going to companies might reasonably be considered measures of the extent to which the market in patented technologies had developed, and indicate clear improvement over time. The two are correlated with each other, and exhibit the same regional pattern as patenting per capita. New England is the leader, with the Middle Atlantic a relatively distant second, and the East North Central lagging a bit behind. Again, there appears to have been a strong positive association across regions between the extent of trade in patents (on a per patent basis) and rates of patenting per capita.

As one examines the differences in the composition of assignments across regions, and how they change over time, the figures in Table 3 seem to suggest a systematic progression in how the market in technology evolved. At first, inventors not only came up with new technological ideas but also developed and commercialized them - sometimes by applying them to their own businesses, sometimes by selling partial rights to their ideas to producers in different geographical markets, and sometimes by doing both. As the market for technology expanded and matured, inventors seem to have employed it to mobilize support for their activities. For example, during the early 1870 s assignments at issue often involved the transfers of shares of patents to groups of individuals who were 
not coinventors, but who generally resided in the vicinity of the patentee, and it is likely that these partial assignments compensated local partners for advances of capital to support the development and commercialization of the inventions. Over time, however, patentees increasingly relinquished all property rights to their inventions by the time of issue, assigning their rights in entirety to companies. These types of assignments would seem to reflect the most pronounced movement toward specialization at invention by patentees, and the transition to this latter phase occurred most rapidly in the regions with historically higher rates of patenting per capita and proportions of patents assigned, such as New England. ${ }^{13}$

The robust regional correspondence between the extent of the market in technology and patenting should not be surprising. On one hand, investments in the establishment of firms and institutions conducive to trade in patented technologies would be expected to concentrate in areas where rates of invention were already high; such

${ }^{13}$ There were several kinds of relationships between patentees and assignees that led to assignments to companies. The first, one that appears to have been predominant until late in the nineteenth century, was when an inventor assigned his patent in an arm's length transaction to a company with which he had no long-term association. A second kind of relationship involved an inventor assigning his patent to the firm that employed him in a long-term association. This type of relationship between patentees and assignees seems to have accounted for only a modest proportion of all assignments to companies through the $1920 \mathrm{~s}$. The third kind of relationship was when an inventor assigned his patent to a firm he was an officer or other principal of. We have found strong evidence that this sort of relationship became more common during the early twentieth century, especially among the most productive inventors. These types of relationships between patentees and assignees have somewhat different implications for the degree of specialization by patentees at invention, and for the relative importance of a market in technology in obtaining that degree of specialization. Much remains unclear however. Of particular interest is the third type of relationship. If the patentee had originally formed the company as a means of raising capital for supporting his inventive activity, the interpretation of an assignment would be different than if the company had made the inventor an officer as a way of tying him to the firm. One would also like to know whether the company was an enterprise that exploited his inventions in the course of its many other activities, or whether it was an enterprise that was relatively specialized at inventive activity. This latter type of firm could extract income from inventions by licensing or selling off the rights to other firms, or through sales of products embodied with the new technology. See Naomi R. Lamoreaux and Kenneth L. Sokoloff, "Inventors, Firms, and the Market for Technology in the United States in the Late Nineteenth and Early Twentieth Centuries," in Naomi R. 
locations presumably offered the best prospects for returns to participating in the market for technology. On the other, firms and institutions conducive to trading in this market would stimulate greater specialization and productivity at invention nearby by increasing the net returns inventors could expect from making a given discovery (accordingly encouraging individuals with a comparative advantage to make appropriate investments in invention, including human capital to augment their productivity at invention) and by making it easier for inventors to raise capital to support their inventive activity. More developed market institutions in a city or region would also attract individuals already inclined to specialize at invention to move to the respective location. Greater specialization by inventors, whatever the source, would in turn stimulate more investment in firms and institutions involved in the patent trade. Such self-reinforcing processes between high rates of invention and the evolution of the market for technology may well have contributed to persistent and correlated regional differences in both rates of patenting per capita as well as of assignment of patented technologies.

Table 4, which uses the geographic distribution of patent attorneys in 1883 as a proxy for access to the market for technology, provides further support for the workings of these selfreinforcing processes. The figures indicate that patent attorneys were overwhelmingly concentrated in New England and the Middle Atlantic, where patenting rates had long been much higher than elsewhere in the country. Even though less than 30 percent of the nation's population resided in these two regions ( 8.0 and 20.9 percent respectively in 1880 ), they were home to more than two-thirds of the patent attorneys in the U.S. outside of Washington D.C. (exceeding their share of patents to U.S. residents as well). The impression that patent 
attorneys and agents tended to set up their shops where large numbers of patents were produced is further strengthened by the estimates of patenting per capita by urbanization class within region reported in Table 5. Patent attorneys were highly concentrated in big cities, which throughout our period generated many more patents per capita than did rural or less urbanized areas within the same regions. Moreover, we will see below that trade in patents was disproportionately conducted in big cities, not only relative to population but also relative to the already disproportionate number of patents generated there.

Finally, another approach to exploring whether patenting activity was related to the expansion of trade in patented technologies is to examine whether the behavior of inventors changed in the way theory would suggest as the market for technology evolved. Specifically, one would expect individuals with a comparative advantage in invention to increasingly specialize in that activity, realizing the returns to their discoveries by selling off the rights to them, and, consequently, that the patents awarded would tend increasingly to be received by specialized inventors. In Table 6 we subject this idea to a test of consistency with the evidence, and find that the share of patents awarded to inventors with long-term commitments to patenting did indeed increase dramatically over the nineteenth century. ${ }^{14}$ The figures indicate that a major shift occurred, especially during the period from the early 1840 s to 1870 when the rate of patenting per capita exploded, with the proportion of patents awarded to individuals who received ten or more patents over their careers rising from

Countries (Chicago: University of Chicago, 1999).

${ }^{14}$ We obtained the estimates for 1870-71, 1890-91, and 1910-11 by selecting from our three crosssectional samples inventors whose last names began with the letter " $\mathrm{B}$ " and collecting information on all the patents these inventors received in the twenty-five years before and after they appeared in the respective sample. We then grouped the inventors according to the total number of patents they obtained over the fifty-year period and calculated how all the patents in each cross-section were distributed across these groups. Finally, we compared our results with data on career patenting for the period 1790-1842 compiled by Kenneth Sokoloff and 
below 5 percent in the three early cross-sections to 25 percent or more in the three crosssections between 1870 and 1911 . The early 1800 s were a democratic era of invention, when a broad segment of the population was acquainted with the basic elements of the technology in use, and the typical inventor accounted for only one or two patents over his or her lifetime in the course of carrying out his trade. The rapid expansion of the market for patents that began during the second third of the nineteenth century, however, made it easier to extract returns from technological discoveries by selling off patent rights, and coincided with the emergence of a class of inventors who were relatively specialized at inventive activity as well as a rise in rates of patenting overall.

Thus far, we have highlighted two distinct types of aggregate or regional patterns that are consistent with the view that the growth and general contour of inventive activity over the mid- to late-nineteenth century was associated with the evolution of a market in patented technologies. First, we noted how very substantial growth in patenting per capita during the middle of the century was realized during roughly the same period that trade in patents expanded greatly, and how these developments coincided with a dramatic increase in the prominence of highly specialized inventors among patentees. Second, a variety of indicators of this market in technological information were strongly correlated across geographic areas with patenting per capita.

Although the evidence for an empirical association between inventive activity and the development of the market for technology is impressive, the hypothesized linkage between productivity or specialization at invention and the practice of selling off patent rights 
must be explored at the level of individual inventors to gain both more confidence in and a better understanding of the patterns in the data. In Table 7, we present three cross-sectional regressions, estimated over the cross-sectional samples of patents from 1870-71, 1890-91, and 1910-11. The dependent variable is the log of the number of patents awarded to the patentee in the respective two-year periods, and the independent variables include dummies for the region in which the patentee resided, whether he resided in an urban county or a major metropolitan center, the sector in which the patent was classified, the log of the annual rate of patenting per capita in the patentee's home county, and a set of dummies for whether the patent was assigned at issue and for categories of assignments. The key result is that even after controlling for location and the sector with which the invention was concerned, patentees who assigned their patents to companies were awarded more patents per year on average throughout our period - in each of the three cross-sections. Because the great majority of assignments at issue not going to companies seem to have involved transfers of shares of the respective patent to local partners or suppliers of capital, this finding is quite consistent with the idea that the patentees who tended to sell off the full rights to their inventions were the most specialized and productive at invention. The inventors who maintained a share of their patent may not have been anymore specialized at invention than patentees who did not assign, and indeed there was no statistically significant difference between those who assigned their patents to individuals and those who did not relinquish the rights to their inventions until 191011. By then, with technology more complex and costly to develop, patentees who lacked partners or associations with companies, or whose inventions did not attract quick buyers,

States, 1790-1846," Journal of Economic History, 50 (June 1990), pp. 363-78. 
were probably at a serious disadvantage in maintaining major commitments to inventive activity.

Several other results from the regressions also lend support to our argument. Most directly, the finding that patentees residing in counties with high rates of patenting per capita, urban counties, and in New England or the Middle Atlantic - all areas with evidence of a better developed market for technology -- filed significantly more patents than those located elsewhere is consistent with our notion that the most productive inventors were attracted to opportunities to trade the rights to their discoveries. Moreover, our view that the increasing complexity of technology over time encouraged inventors to invest in human capital useful in carrying out inventive activity, and to specialize accordingly, is supported by the coefficients on the dummy variables for the sector in which the patent was intended. After controlling for other variables, patentees in manufacturing, energy, and transportation received more patents than those working in other sectors, and both the magnitude and statistical significance of these differentials increased over time.

The cross-sectional regressions are interesting, but there is a question of how well specialization or productivity at invention can be measured from information on patenting activity in only one or two years. In order to obtain a more accurate measure, we constructed a data set composed of the records of patenting activity over fifty years for 561 patentees. The 561 individuals consisted of all of the patentees in our randomly-selected cross-sectional samples for $1870-71,1890-91$, and 1910-11, whose family names began with the letter 'B'; hence we refer to this as our ' $\mathrm{B}$ ' sample. ${ }^{15}$ We traced each of these patentees in the Annual

\footnotetext{
${ }^{15}$ More patentees had family names beginning with ' $B$ ' than with any other letter. On average, they account for roughly $11 \%$ of patents filed. More information about the construction of the data set is provided in the note to Table 6.
} 
Reports of the Commissioner of Patents both back and forward twenty-five years to assemble what we refer to as the "career" record of patenting. In total, the 561 patentees received 6057 patents over their respective "careers" of fifty years, with each patent record being an observation in the data set, and career totals and characteristics of the respective patentee linked to each of his patents.

In Table 8, we report descriptive statistics on the "career" records of the patentees included in this sample, for each of the particular cross-sections from which the 561 patentees originally appeared and by whether and to whom the patent was assigned. In the upper panel of the table, the averages of the total number of patents received by the patentee over his career, of the number of years between his last patent and first patent, and of the proportion of all patents received over his career that were assigned at issue, were computed over the 561 patents of the 561 patentees that were originally included in the cross-sectional samples; the lower panel contains the statistics computed over all 6057 patents. The two sets of figures are in a sense analogous to unweighted and weighted averages of the patentee characteristics, but are not the same because a single patentee can have different patents counted in different assignment categories.

The most striking and robust finding is that in all three "cohorts", patentees who assigned their rights away at issue to companies had very different careers of inventive activity than other groups of patentees - especially those who did not assign. They received many more patents over time, were active at generating patentable inventions for a much longer period, and assigned away a high proportion of the patents they were awarded. The stark contrasts are evident as early as the 1870-71 cohort of patentees, who were active long before the large-scale R \& D laboratories of the twentieth century. The means computed over 
patentees (patents) indicate that those who assigned their patent to a company at issue received 30.0 (35.9) patents over their careers on average, whereas those who did not assign, those who assigned away only a share of their patent, and those who made full assignments to individuals were granted $8.0(20.0), 5.4(19.3)$, and 5.3 (27.3) patents respectively. The average lengths of career spanned 25.5 (26.6) years for patentees assigning to companies, as opposed to 13.2 (21.5), 10.6 (20.7), and 12.0 (26.1) years respectively for the other three groups of patentees. The findings that inventors who assigned away their patent rights to companies were more specialized and productive at invention over their careers holds across different cohorts, measures, and weighting schemes, and thus provides support to the idea that the evolution of the market for technology encouraged the emergence of a class of highly productive inventors who relied on the sale of their patents to extract the returns to their efforts.

Patentees making full assignments at issue to individuals were more productive at invention than their counterparts who either didn't assign their patents at issue or only assigned away a share of their rights to individuals. Because their decisions to sell off all of the their rights suggest that they too were relatively specialized at inventive activity, this class of patentees is an analytically important group, in that they allow us to distinguish the characteristics of inventors who sold off their patents in full to individuals from those who made full assignments to companies - a significant distinction for those who question whether assignments at issue from patentees to companies were typically conducted at arm's length. When the comparisons are based on means computed over all patents (lower panel), or on the overall average of individual patentees (pooling all three cohorts), inventors who sold off their rights entirely to individual assignees do indeed seem to have been more specialized and productive at patenting over their careers. The results are not robust to the within-cohort 
means reported in the upper panel, but given the small number of individual inventors who made full assignments to individuals (7,6, and 6 in the three cohorts respectively), these estimates, based on one patent per inventor, may not be meaningful.

In general, the small number of observations in some cells might make one cautious in drawing firm conclusions, and especially about changes over time. Nevertheless, the results overall, including the differences in the means and distributions of observations between the two panels, seem to suggest that there were two rather sharply differentiated classes of inventors. The first was composed primarily of individuals who tended to retain control of the relatively few patents they received over a rather short careers at invention. These occasional inventors had little involvement with the market for technology. The other class of inventors, in contrast, had careers that were largely shaped by the market. They assigned away a high proportion of their inventions, to either companies or individuals, and were quite focused on generating patented inventions - receiving many patents over careers at invention that extended over several decades. Most prolific patentees fell into this second category, and it would seem reasonable to argue on the basis of these data that the market for technology played a central role in the processes and organization of inventive activity during this era.

Multivariate analysis allows us to examine these patterns more carefully, by controlling for other factors that might be expected to be associated with the productivity of an inventor over time and the length of his career. Table 9 reports the results for two sets of regressions estimated over all 6057 patents, employing the log of each of these measures of specialization at invention respectively as the dependent variable. The independent variables include dummy variables for the region of the patentee, the degree of urbanization in the county of his residence, and for the cohort (or cross-section) that the patentee in the 'B' sample was drawn 
from. The other independent variables are defined as the proportion of career patents that were assigned fully at issue to individuals other than the patentee, the proportion of career patents that were assigned at issue to companies, and interaction terms between the variable for the proportion assigned to companies and the two respective dummy variables for the $1890-91$ and 1910-11 cohorts of patentees. The intercept represents a patentee, residing in a rural county of the Middle Atlantic and drawn from the 1870-71 cross-sectional sample.

The regressions provide further substantiation of the patterns noted in the discussion of the descriptive statistics. Patentees who made full assignments at issue of their patents, whether to companies or individuals, received many more patents over their careers, assigned higher proportions of their patents, and had much longer careers than other classes of patentees. The estimated point coefficients on the proportion of patents assigned to companies are very large, and the inclusion of interaction terms with the year-cohort dummies indicates that the strength of these associations (both in terms of size and statistical significance) did not change all that much over time (cohorts). The implication is that inventors who relied on the sale of the rights to their patents followed very different career paths from those who retained the rights to commercialize their inventions themselves (or with partners), and were more likely to be highly productive at invention over their careers. It is striking that this pattern is already evident in the 1870-71 cohort, suggesting that this association between trade in patent rights and high productivity as an inventor likely developed rather early. The coefficients imply that inventors who assigned to companies typically accounted for more patents, and had slightly longer careers, than those who made full assignments to individuals, but the differences between these two classes of patentees pale relative to those that between them and the other two classes - patentees who did not assign or those who assigned away only a share of their 
rights. Whether an inventor used the market for technology to extract the returns to his inventive effort by making full assignments before issue seems clearly to have been the most powerful correlate with productivity at patenting over his career. ${ }^{16}$

Also of relevance to our general hypothesis are the findings that patentees residing in urban counties, and especially in counties with cities of 100,000 or more, produced substantially more patents over their career (and had longer careers, in the latter case) after controlling for other characteristics. Similarly, patentees residing in the regions with persistently higher levels of patenting per capita and assignment activity, like New England, the Middle Atlantic, and the Middle West, had higher numbers of career patents. These patterns are consistent with the view that the more productive or specialized inventors were attracted to locations where the market for technology was better developed or especially active. Finally, the coefficients on the cohort dummies suggest that inventors from the 1890-91 and 1910-11 cohorts were more productive at patenting over their careers, and had longer careers, than those from the 1870-71 cohort. This is in general consistent with the notion that the increasing amounts of investment in human capital required to be an effective inventor was leading to greater specialization at invention over time, but precisely when these measures of long-term commitment are estimated to peak depends upon the other variables controlled for.

Skeptics might object that the observation that patentees who assigned their patents at issue to companies received so many more patents on average, and had longer careers, was due not to inventors using the market for technology to facilitate their specialization at invention, but rather to their being employees of the companies in question. In such a case, the

\footnotetext{
${ }^{16}$ One simple way of illustrating this point is to see how the explanatory power of the regressions increase substantially when the independent variables reflecting the proportions of total patents assigned (and the proportions assigned in a particular manner) are included.
} 
appearance of higher productivity of patentees who assigned away the rights to their inventions might simply be attributable to firms underwriting the cost of the patent applications, and thus be misleading about the extent of arm's-length transactions. Although these is a serious caveat that deserves careful evaluation, the finding that inventors who made full assignments to individuals were also highly productive and had long careers at invention tends to undercut the force of the objection, because it seems implausible that these individual assignees were longterm employers of the inventor. That the association between full assignment and specialization at invention was apparent as early as 1870-71 also makes it difficult to believe that the patterns was attributable to assignments within firms - between inventor-employees and employers. Moreover, in other work, we carried out a rather extensive investigation of the relationships between the patentees in the ' $\mathrm{B}$ ' sample and their assignees, drawing on information retrieved about their places of work and job titles, and found that the most highly productive inventors were generally not employees of the companies they assigned their patent rights to. ${ }^{17}$ Instead this class of inventors behaved entrepreneurially, selling their patents to different assignees, and to firms other than their employers. It was not until the turn of the twentieth century, that the nature of the market for technology began to change again, with a decrease in the proportion of arm's-length transactions and a corresponding increase in the assignments made at issue by patentees who were officers or other principals in the companies specified as assignees. This decline during the early decades of the twentieth century in the independence of the most productive inventors from the companies to which they assigned their patents is an extremely interesting phenomenon. Why the change occurred is not yet clear, but it does not negate our

\footnotetext{
${ }^{17}$ We report on this investigation in Lamoreaux and Sokoloff, "Inventors, Firms, and Markets".
} 
finding that the market for technology had supported the rise of an important class of highly specialized independent inventors long before the spread of large-scale R \& D laboratories.

In summary, the analysis of how the productivity at patenting and other characteristics of inventors varied with their use of the market for technology contributed strong, if circumstantial, support for our argument that the development of trade in patent rights encouraged creative individuals to specialize in invention, with positive consequences for the pace of technological change more generally. In the next section of the paper we explore the evolution of a set of institutions that was central to this trade intermediaries - and examine whether the patterns of services they provided are consistent with our interpretation. If the ability to extract returns from invention by selling off patent rights was crucial to the organization of highly productive inventors, then one would expect such individuals to be disproportionately associated with intermediaries who were more specialized at trading in the market for technology and more effective at carrying out transactions (or making deals) therein.

\section{IV}

Although patentees, assignees, or essentially anyone could act as a middleman in organizing the sale of a patent, there is reason to believe that the efficiency of such exchanges improved over time as intermediaries who were relatively specialized in particular segments of the market for technology emerged. Judging from the records of the assignments filed with the Patent Office, inventors had already begun to employ intermediaries by the 1840 s, when multiple assignments of a single patent to distinct geographic areas were a common practice. These intermediaries were most often local 
attorneys or businessmen who knew what kinds of patents were likely to be salable in their districts. As assignments became national in scope, however, other means of marketing patents had to be developed. Moreover, the relations between patentees, assignees, and intermediaries also had to change as inventive activity became more and more costly and the province of increasingly specialized individuals. Agents in outlying areas were no longer very useful. Patentees now needed intermediaries who were able to tap into networks of businessmen and firms operating in national markets, provide them with information about what types of inventions were in demand, and help them raise capital to support their inventive activity. Alternatively, patentees or assignees could play the role of intermediary themselves. Although many did, there were problems with this approach. Not only was marketing or searching for a patented invention resource-consuming (distracting inventors, say, from more creative tasks in which they presumably had a comparative advantage), but such part-time agents were probably less efficient at intermediation than specialized agents because of scale economies associated with investment in information acquisition and reputation building. ${ }^{18}$

Indeed, over time, the role of intermediary came increasingly to be played by patent agents and lawyers. The ostensible function of these specialists was, of course, to help inventors navigate through the Patent Office's application process and, in the case of lawyers, to defend their clients' patents in interference and infringement proceedings. In the course of their business, however, patent agents and lawyers obtained a great deal of information about participants on both sides of the market for technology. Buyers used

${ }^{18}$ A more comprehensive discussion of the issues related to the organization of intermediation is provided in Naomi R. Lamoreaux and Kenneth L. Sokoloff, "Intermediaries in the U.S. Market for Technology, 1870-1920," working paper, 1999. 
them for assistance in evaluating the merits of inventions they were interested in purchasing, and through repeat dealings with such customers, these specialists obtained a great deal of information about the kinds of patents firms were interested in buying as well as personal insight into the character of the people involved. Inventors used patent agents and lawyers to file applications, giving them advance information about technologies about to be patented. In addition, inventors frequently developed long-term relationships with their patent agents that encouraged them to try out new ideas on these specialists. ${ }^{19}$

In theory, intermediaries specialized in the market for technology should have lowered costs in trading patents and expanded the extent of this market. In so doing, the growth of these intermediaries would accordingly stimulate a greater commitment of resources to inventive activity by inventors and by society at large. If this hypothesis were correct, however, and there were fixed costs to an inventor and specialized agent establishing a relationship (such as becoming familiar with each other's work), then one would expect that the patentees dealing with specialized agents would be more productive over time than those utilizing other kinds of intermediation, and conversely that the specialized agents would disproportionately be dealing with the most specialized and productive inventors. This pattern of matching would arise because the more specialized inventors would have more to gain from selling his patents through a more efficient or

${ }^{19}$ For example, when Joseph Arbes, a fur manufacturer in New York City who also invented sewing machines, came up with an idea for a blind stitching machine that would use a flat sided needle, he immediately dispatched a sketch of the needle to his patent attorney, William E. Knight, for a judgment as to its potential patentability. He had not even experimented with the needle on a sewing machine at that point, and both the casualness with which he made the request and the primitive state of his invention at that time suggest that he had an ongoing relationship with his attorney, who acted in part as a sounding board for his ideas. See Lamoreaux and Sokoloff, "Intermediaries". 
lower-cost intermediary, and such specialized intermediaries would seek out clients who would bring them a lot of valuable business.

The rise of specialized intermediaries in the trade in patents is but one, albeit fundamental, aspect of the development of the market for technology over the late nineteenth and early twentieth centuries. It is one, however, whose effects can be systematically studied by using information on the assignment contracts registered with the Patent Office. Clerks in that office maintained a chronologically-organized registry that included the full texts of the assignment contracts. They also kept a Digest (also organized chronologically but in separate sets of volumes distinguished by the first letter of the surname of the patentees in the registry), which included a summary of the basic details of each assignment as well as the name and address of the "correspondent" to which all correspondence from the Patent Office was to be addressed. We believe that these correspondents were not only primarily responsible for the performance of the legal tasks associated with drawing up and maintaining the records for their assignment contract, but often served as intermediaries between the buyers and sellers. ${ }^{20}$

We constructed a sample from this source by collecting the information on all of the assignment contracts filed with the Patent Office during the first three months of 1871 , 1891 , and 1911 for patents whose inventors had surnames beginning with the letter 'B.' Because some of the contracts covered more than one patent, we sometimes focus on the individual patent assigned as the unit of analysis, and sometimes on the individual assignment contract. Overall, the sample encompasses 286 contracts (involving 437 patents) from $1871 ; 423$ contracts ( 858 patents) from 1891, and 614 contracts (880 
patents) from $1911 .^{21}$ In order to more fully examine how the type and characteristics of patent assignments varied across different kinds of inventors, we retrieved for each of the assigned patents in our sample, a five-year history of all patents received and assigned (at issue) by the respective patentee, using the year the assigned patent was granted as the mid-year (thus, we looked two years back, and two forward, from the base year).

Each assignment contract (and the patents it included) were categorized by the identity of the respective correspondent. Working with lists of patent agents and lawyers from 1883 and 1905, we distinguished correspondents (generally individuals, rather than firms) who were formally registered with the Patent Office in at least one of these two years as a separate (and likely the most specialized on average) class of intermediaries. Correspondents who were either the patentee, the assignor, or assignee of the patent specified in the contract were grouped together in a second category of intermediaries. A third category consisted of third parties who did not appear on either of the two lists of registered agents we relied on, but it seems likely that some of the correspondents so classified would have been identified as registered patent agents if we had rosters for more years. Finally, the 'unknown' category of correspondents includes those cases where no correspondent was listed in the Digest. These cases were almost entirely due to the patent in question being assigned together with a patent issued to an inventor whose surname began with a letter other than ' $\mathrm{B}$ '.

${ }^{20}$ As will be evident from the data presented below, a substantial and increasing proportion of the correspondents were registered with the Patent Office as patent agents or lawyers.

${ }^{21}$ Our analysis treats as contracts cases where a single contract assigned multiple patents from the same assignor to the same assignee, as well as instances in which several assignments dealing with the same patent were evidently signed and filed with the Patent Office at the same time. Hence, assignments filed together in which patentee Smith assigned his patent to Jones in the first one, and then Jones assigned to Burns in a second assignment, were treated as falling under the same contract. 
In Table 10 we present descriptive statistics computed over the assignment contracts for each of the correspondent classes in 1871, 1891, and 1911. As is immediately evident, the relative prominence of registered patent agents in the trade of patent rights increased over time. They served as correspondents for 26.1 (29.7) percent of the patents (contracts) assigned in 1871 , with their shares increasing to 42.7 (51.8) percent in 1891, and to 55.7 (58.1) percent respectively in 1911. Another way of gauging the changing composition of correspondents is to focus on the continuous decline in the proportion of patent assignments mediated by one of the principals (patentees, assignors, or assignees)-from 33.0 (33.9) in 1871 to 11.2 (9.5) percent in 1911. It is clear from these figures that third-party intermediaries were already dominant in this market for patented technologies by 1871 , and that the share of the trade carried out through relatively specialized agents increased over time.

That registered agents were indeed relatively specialized intermediaries is indicated by the higher numbers of assignment contracts they handled, as compared to the record of correspondents in the other categories. For example, in 1871 the average registered agent served as the correspondent on 2.36 of the contracts included in our sample, whereas the averages for principals and unregistered third parties are 1.05 and 1.26 respectively. These figures, of course, greatly underestimate the total number of assignments handled annually by the correspondents, as they are based on only a small subset of all contracts ( 3 months of assignments for patents whose patentees had surnames beginning with the letter ' $\mathrm{B}$ '). ${ }^{22}$

The use of registered patent agents was especially prevalent in those segments of the trade in patents where greater effort or specialization by intermediaries would seem

\footnotetext{
${ }^{22}$ Patentees whose surnames began with ' $B$ ' accounted for roughly 11 percent of all patents.
} 
likely to have been beneficial, if not essential. One example is that registered agents were much more likely to have been involved in assignment contracts made before the issuance of the patent, which required involvement at an earlier and more delicate stage of inventive activity, than were other types of correspondents. In 1871,61 percent of the assignment contracts handled by registered agents were entered into before issue, as opposed to 8 and 23 percent respectively for those where the correspondents were principals or other third parties. $^{23}$ This stark difference implies that registered agents were indeed providing a higher quality of intermediary service, one that we normally associate with better developed markets - sales were being effected earlier or more quickly. Another reflection of registered agents being more specialized than other intermediaries is their greater orientation toward the more extensive (national) market, and less involved with assignments pertaining to a specific geographic area. As early as 1871 , fully 89 percent of the contracts for which the correspondent was a registered agent were national, compared to 70 percent for unregistered third parties and 51 percent for principals. Patent agents were also more likely to be involved in primary, as opposed to secondary, assignments and were increasingly so over time. ${ }^{24}$ Finally, while inventions generated by patentees residing in major metropolitan centers were generally much more likely to be assigned than those discovered elsewhere, they were especially likely to be handled by registered agents. Large cities, with their much higher patenting and assignment rates, as

\footnotetext{
${ }^{23}$ This result is robust to controlling for whether the assignment was primary or secondary, as well as for the characteristics of the patentee.

${ }^{24}$ Although we lack systematic information about the prevalence of licensing, there are many indications that the volume of licensing increased substantially over time relative to patent assignments. Since registered agents were generally leaders in developing new forms of contracts, their lower propensity to handle secondary assignments may be due to a higher propensity to be involved in licensing. We base our judgment about how progressive registered agents were on their much earlier adoption of
} 
well as their disproportionate share of very productive inventors, were the hubs of the market for technology, and the particular prominence of registered agents in sales of patents conducted there constitutes further evidence that they were a rather distinctive and more specialized class of intermediaries.

Consistent with what we have argued above, assignments by inventor-employees to large firms do not seem to play a much of a role in accounting for the growth over time in, and patterns of, use of patent agents. For example, the reported percentages of the patent assignments going to companies (as opposed to individuals), show that the trend over time toward assigning patents to companies accounted for very little of the change in the composition of correspondents. This inference follows from the rather small differences between the fraction of patent assignments handled by registered agents that went to companies (28,39, and 61 percent in 1871, 1891, and 1911 respectively) and the fractions of those handled by principals to the assignments $(24,28$, and 55 percent in the respective years) as well as by unregistered third parties (20,48, and 42 percent). Moreover, the differences we have observed in the characteristics of patentees using different types of correspondents are robust to controlling for whether the assignments was made to a company or an individual.

A more direct test of the idea that the rise of specialized intermediaries made a difference for the organization and levels of inventive activity is to compare those patentees who used registered agents to intermediate in the sales of their patent rights, with patentees who either organized their assignments themselves or relied on other principals (assignors or assignees) to do so. If patent agents did indeed offer some 
advantage in trading patent rights, such as more efficient (higher quality service) intermediation or lower transactions costs, one would expect that the inventors who developed relationships with them would be those who were both more specialized at patenting and more inclined to extract the returns to their efforts by selling off the rights to their inventions. As Table 10 indicates, such a pattern did develop over time. In 1871, the average five-year total of patents awarded to patentees whose contracts were handled by registered agents was roughly similar to the numbers for patentees who had used other types of correspondents, but the former group did assign a higher fraction of their patents at issue over those five years. By 1891, however, the more specialized inventors were clearly disproportionately matched with the more specialized intermediaries. On average, patentees whose patents were sold by registered agents received 6.61 patents (4.90 if computed over contracts), as compared to 3.65 (3.43) and 5.80 (5.17) for those whose patent assignments were arranged by principals or unregistered third parties. They also had the highest rates of assignment. These contrasts grew even more striking over time. By 1911, inventors whose patents were assigned through registered agents were again the most productive or specialized - with 6.92 (5.06) patents over five years, as compared to 2.28 (2.04) for those whose patents were assigned by correspondents who were principals. In summary, the examination of the assignment contract data yields strong evidence that the rise of registered patent agents reflected the emergence of more specialized intermediaries in the market for technology, and was indeed associated with improvements in the quality of intermediation. Although this follows from the obvious success of registered agents in the competition with other intermediaries, as judged by 
changes in their market share over time and higher market share in places with high inventive activity, their superior services in intermediation are perhaps best illustrated through how quickly they were able to sell a patent relative to its date of issue. Given that registered agents provided better intermediation, it is not surprising that the most productive and specialized inventors came to be highly disproportionately represented among their inventor clients. Inventors who were specialized at invention and depended on selling off the rights to their patents to extract the returns to their efforts would naturally be most concerned with obtaining high quality (or lower cost) intermediation. The improvement in intermediation, in turn, reinforced the focus of inventors on generating patentable inventions. Both the association of the more specialized inventors with the more specialized agents, as well as the greater speed of closing assignment deals is consistent with the impression that patent agents frequently had long-term relationships with their major clients such that they could begin the process of matching buyers with sellers, even before patents were applied for. ${ }^{25}$

\section{$\mathrm{V}$}

Major increases in rates of invention as well as dramatic growth in the relative importance of highly specialized inventors as generators of new technological knowledge were among the fundamental changes in the patterns of inventive activity that occurred in

\footnotetext{
${ }^{25}$ Drawing on other sources of evidence, we examine the relationships between patent agents and their inventor clients in Lamoreaux and Sokoloff, "Intermediaries in the U.S. Market for Technology," and find that many did maintain long-term associations and were often involved in marketing inventions well before they were patented. The observations that patentees with historically high patenting and assignment rates disproportionately dealt with registered agents and made assignments before issue are also consistent with our view.
} 
the U.S. during its early stages of economic growth. Although conclusively demonstrating causality is difficult, we have argued that an active market for technology evolved over the nineteenth century, and that it played a central role in these developments. Relying on records pertaining to patents and their sales, we have shown not only that there was a high volume of trade in patented technologies, but also that such commerce and patenting activity were closely associated with each other. Indeed, a broad variety of evidence seems consistent with what theory would suggest, that improvements in the capabilities to trade in technology would stimulate increases in specialization at invention by those with a comparative advantage in that activity, as well as increases in rates of invention more generally. ${ }^{26}$

One of the most basic tests of our hypothesis was to examine how the pace and organization of invention varied with trade in patented technologies over time and place. As we would expect, they grew together during the critical middle third of the nineteenth century between the 1836 change in the patent law, which strengthened the property rights of patentees and their assignees, and 1870. Rates of patenting per capita on a national basis boomed, increasing more than ten times, alongside a proliferation of patent agents, periodicals focused on inventions, and other institutions conducive to trade in technology. Moreover, employing several different measures of the extent of this market, we found that that the patenting rates were highest, and increased the most over time in regions like New England and the Middle Atlantic, where it was most developed. What seems to have happened is that the institutions of the market evolved most rapidly in areas

\footnotetext{
${ }^{26}$ It seems quite reasonable to assume in this context here that the demand for patented inventions is downward-sloping, if not elastic as well. The increase in rates of invention would be expected to be highly concentrated in those geographic areas with an improved capability to trade patents.
} 
where rates of invention were high, and the resulting improvements in the capabilities for trading in patents in turn stimulated higher rates of patenting - both by resident inventors as well as those who moved in to take advantage of the greater opportunities available in such locations. These mutually-reinforcing processes likely contributed to the marked pattern of geographic persistence in relative levels of inventive activity that extended over the nineteenth and into the twentieth century.

Another level of tests pertained to the behavior of individual inventors. The logic of our view that the emergence of the market for technology stimulated increases in specialization at invention, and in invention overall, suggests that the most productive inventors would be disproportionate sellers of the rights to their inventions, and that their relative importance in the generation of inventions would have grown with the development of the market for technology. The results here were again consistent with the general hypothesis. Patentees who assigned away the full rights to their patents, and especially to companies, were more productive at patenting than their counterparts who did not throughout the period under study. Furthermore, the proportion of patents accounted for by inventors who were relatively specialized at invention increased sharply with the expansion of trade in patents and the acceleration of patenting that took place over the middle third of the nineteenth century. Overall, the evidence seems to indicate that a substantial group of inventors took advantage of the improving market for technology to specialize more in the generation of patentable inventions, and that the rise of these specialized inventors contributed powerfully to the general increase in patenting per capita. No doubt the enthusiasm with which they embraced this strategy for making the best of their talents, as well as the changing environment for trading in patents, was 
partially attributable to the greater investments in human capital that were becoming increasingly necessary for those engaged in inventive activity as technology grew more complex over time.

Finally, we subjected our interpretation to yet more scrutiny by examining whether the most productive inventors were the most sensitive to incremental improvements in the market for technology. If they were indeed particularly specialized at invention, and thus dependent on trading away the rights to their patents, one would expect them to have been especially attracted to advances which improved the efficiency of carrying out such transactions. Although the development of the market for technology encompassed many distinct changes that are difficult to study with any precision, we sought to test the notion by examining whether it was the most productive inventors who were most inclined to use specialized intermediaries like registered patent agents or attorneys in selling off their patents. The emergence of such intermediaries, though admittedly quite heterogeneous, could reasonably be considered an institutional change that led to a better articulated and integrated market for patents, and the observation that they did disproportionately deal with inventors who produced more patents is consistent with our view. ${ }^{27}$

The patent system is often celebrated for the stimulus to invention it provides by granting limited monopoly rights to inventors for the use of their discoveries. Although this effect is certainly substantial, the strong association of patenting with trade in new

\footnotetext{
${ }^{27}$ Some patent agencies, like Munn and Company, appear to have had a high-volume business, focusing more on helping large numbers of patentees obtain patents, and less on the time-intensive marketing of specific inventions. Other agencies, or individual agents, appear to have provided higher quality service to a smaller number of clients. Although both classes of agents were in some sense specialized, it is the latter type of intermediary that was probably most likely to be dealing with the highly specialized and productive inventors. See Lamoreaux and Sokoloff, "Intermediaries in the U.S. Market for Technology", for an extensive discussion of the activities of specific patent agents.
} 
technological knowledge over the late nineteenth and early twentieth centuries, suggests that its specification of tradable assets in technology was another fundamentally important way in which the patent system has stimulated inventive activity. In establishing a basis for extensive trade in the rights to new technological knowledge, the patent system not only enhanced the potential returns to particular inventions, but also facilitated the realization of economies to specialization at invention by independent inventors or small enterprises. Although some have been skeptical of the feasibility or extent of arms-length transactions of this sort, it is clear that they were very common through the nineteenth century and that access to, or involvement in, a market for technology had a profound impact on the patterns of inventive activity. It remains to be determined why the independence of the most productive inventors appears to have declined during the twentieth century, at least until recently. ${ }^{28}$ However, the evidence we have examined suggests this change in the organization of inventive activity was unlikely to have been due to high costs in transacting over technology. Other possible explanations, such as advantages large enterprises may have had in raising capital or improvements in personnel management which facilitated the realization of economies of specialization by individual inventors within large firms, seem deserving of investigation.

\footnotetext{
${ }^{28}$ See Lamoreaux and Sokoloff, "Inventors, Firms, and Markets".
} 
TABLE 1

ANNUAL PATENTS RECEIVED PER MILLION RESIDENTS, BY REGION 1840-1911

\begin{tabular}{lcccccc}
\hline \hline & $1840-49$ & $1850-59$ & $1860-69$ & $1870-71$ & $1890-91$ & $1910-11$ \\
\hline New England & 55.5 & 175.6 & 483.3 & 775.8 & 772.0 & 534.3 \\
Middle Atlantic & 51.7 & 129.4 & 332.3 & 563.4 & 607.0 & 488.6 \\
East North Central & 16.6 & 57.3 & 210.3 & 312.3 & 429.9 & 442.3 \\
West North Central & 9.5 & 22.9 & 95.4 & 146.5 & 248.7 & 272.0 \\
South & 5.5 & 15.5 & 26.0 & 85.8 & 103.1 & 114.4 \\
West & ---- & 24.8 & 164.5 & 366.7 & 381.6 & 458.4 \\
U.S. Average & 27.5 & 91.5 & 195.7 & 325.4 & 360.4 & 334.2 \\
\hline
\end{tabular}

Notes and Sources: The rates have been computed from cross sectional samples of patents drawn from the Annual Reports for the Commissioner of Patents for 1870-71, 1890-91, and 1910-11, and from information provided in the introduction to the Annual Report for 1891 . The regional classifications are based on those employed by the Census, except that Maryland, Delaware, and the District of Columbia are included in the Middle Atlantic for the $1840 \mathrm{~s}, 1850 \mathrm{~s}$, and $1860 \mathrm{~s}$, but in the South for the later periods. 
TABLE 2

DESCRIPTIVE STATISTICS ON ASSIGNMENTS MADE BEFORE AND AFTER ISSUE OF PATENTS

\begin{tabular}{|c|c|c|c|}
\hline & $1870-71$ & $1890-91$ & $1910-11$ \\
\hline \multicolumn{4}{|l|}{ New England } \\
\hline Assignment to Patenting Index & 115.1 & 109.5 & 132.4 \\
\hline$\%$ Assigned After Issue & 70.4 & 31.2 & 30.1 \\
\hline$\%$ Secondary Assignments & 26.6 & 14.8 & 12.0 \\
\hline$\%$ Geographic Assignments & 17.1 & 0.8 & 0.0 \\
\hline \multicolumn{4}{|l|}{ Middle Atlantic } \\
\hline Assignment to Patenting Index & 100.7 & 94.8 & 116.3 \\
\hline$\%$ Assigned After Issue & 70.9 & 44.4 & 37.9 \\
\hline$\%$ Secondary Assignments & 33.3 & 16.4 & 11.0 \\
\hline$\%$ Geographic Assignments & 19.1 & 1.9 & 0.7 \\
\hline \multicolumn{4}{|l|}{ East North Central } \\
\hline Assignment to Patenting Index & 96.3 & 118.1 & 104.9 \\
\hline$\%$ Assigned After Issue & 77.7 & 48.5 & 32.8 \\
\hline$\%$ Secondary Assignments & 18.1 & 18.4 & 11.8 \\
\hline$\%$ Geographic Assignments & 34.3 & 5.7 & 1.8 \\
\hline \multicolumn{4}{|l|}{ West North Central } \\
\hline Assignment to Patenting Index & 90.7 & 110.1 & 73.5 \\
\hline$\%$ Assigned After Issue & 77.4 & 48.6 & 42.6 \\
\hline$\%$ Secondary Assignments & 32.3 & 19.2 & 11.0 \\
\hline$\%$ Geographic Assignments & 41.9 & 13.0 & 2.6 \\
\hline \multicolumn{4}{|l|}{ South } \\
\hline Assignment to Patenting Index & 60.0 & 68.9 & 68.0 \\
\hline$\%$ Assigned After Issue & 74.4 & 42.3 & 48.2 \\
\hline$\%$ Secondary Assignments & 27.9 & 11.3 & 19.1 \\
\hline$\%$ Geographic Assignments & 20.9 & 6.2 & 2.5 \\
\hline \multicolumn{4}{|l|}{ West } \\
\hline Assignment to Patenting Index & 150.0 & 67.2 & 81.5 \\
\hline$\%$ Assigned After Issue & 59.1 & 57.4 & 36.0 \\
\hline$\%$ Secondary Assignments & 22.7 & 11.4 & 10.4 \\
\hline$\%$ Geographic Assignments & 18.2 & 7.4 & 1.2 \\
\hline \multicolumn{4}{|l|}{ Total Domestic } \\
\hline Assignment to Patenting Index & 100.0 & 100.0 & 100.0 \\
\hline$\%$ Assigned After Issue & 72.3 & 44.1 & 36.5 \\
\hline$\%$ Secondary Assignments & 27.8 & 16.4 & 12.0 \\
\hline$\%$ Geographic Assignments & 22.8 & 4.6 & 1.2 \\
\hline Assignments to Patents Ratio & 0.83 & 0.71 & 0.71 \\
\hline Number of Contracts & 794 & 1,373 & 1,869 \\
\hline
\end{tabular}

Sources and Notes: Our sample consists of all assignment contracts filed with the Patent Office during the months of January 1871, January 1891, and January 1911. These contracts are recorded in Liber" volumes stored at the National Archives. There are a total of about 4,600 contracts in our sample. Only those involving assignors that resided in the United States are included in this table. The assignment to patenting index is based on the ratio of assignments originating in the respective regions (given by the residence of the assignor) to the number of patents filed from that region in 1870,1890 , and 1910 respectively. In each year the index has been set so that the national average equals 100 . The percentage of secondary assignments refers to the proportion of assignments where the assignor was neither the patentee nor a relative of the patentee. The percentage of geographic patent assignments refers to the proportion of assignments where the right transferred was for a geographic unit smaller than the nation. 
TABLE 3

ASSIGNMENT OF PATENTS BY REGION, 1870-1911

\begin{tabular}{|c|c|c|c|}
\hline & $1870-71$ & $1890-91$ & $1910-11$ \\
\hline \multicolumn{4}{|l|}{ New England } \\
\hline$\%$ of Patents Assigned & $26.5(340)$ & $40.8(321)$ & $50.0(264)$ \\
\hline$\%$ of Assignments to Company & 33.3 & 56.5 & 75.0 \\
\hline $\begin{array}{l}\% \text { of Assignments to Group that } \\
\text { Includes Patentee }\end{array}$ & 48.9 & 32.1 & 14.4 \\
\hline \multicolumn{4}{|l|}{ Middle Atlantic } \\
\hline$\%$ of Patents Assigned & $20.6(645)$ & $29.1(669)$ & $36.1(710)$ \\
\hline$\%$ of Assignments to Company & 22.6 & 50.8 & 72.7 \\
\hline $\begin{array}{l}\% \text { of Assignments to Group that } \\
\text { Includes Patentee }\end{array}$ & 44.4 & 35.4 & 18.8 \\
\hline \multicolumn{4}{|l|}{ East North Central } \\
\hline$\%$ of Patents Assigned & $14.7(340)$ & $27.9(505)$ & $32.3(660)$ \\
\hline$\%$ of Assignments to Company & 12.0 & 47.5 & 68.1 \\
\hline $\begin{array}{l}\% \text { of Assignments to Group that } \\
\text { Includes Patentee }\end{array}$ & 70.0 & 41.1 & 21.6 \\
\hline \multicolumn{4}{|l|}{ West North Central } \\
\hline$\%$ of Patents Assigned & $9.0(67)$ & $21.8(202)$ & $17.5(285)$ \\
\hline$\%$ of Assignments to Company & 0.0 & 36.4 & 46.0 \\
\hline $\begin{array}{l}\% \text { of Assignments to Group that } \\
\text { Includes Patentee }\end{array}$ & 83.3 & 56.8 & 42.0 \\
\hline \multicolumn{4}{|l|}{ South } \\
\hline$\%$ of Patents Assigned & $6.4(140)$ & $25.0(216)$ & $22.7(322)$ \\
\hline$\%$ of Assignments to Company & 11.1 & 33.3 & 34.2 \\
\hline $\begin{array}{l}\% \text { of Assignments to Group that } \\
\text { Includes Patentee }\end{array}$ & 77.8 & 57.4 & 53.4 \\
\hline \multicolumn{4}{|l|}{ West } \\
\hline$\%$ of Patents Assigned & $0.0(31)$ & $25.4(118)$ & $21.4(271)$ \\
\hline$\%$ of Assignments to Company & - & 20.0 & 41.4 \\
\hline $\begin{array}{l}\% \text { of Assignments to Group that } \\
\text { Includes Patentee }\end{array}$ & - & 73.3 & 44.8 \\
\hline \multicolumn{4}{|l|}{ All Patents, Including Foreign } \\
\hline$\%$ of Patents Assigned & $18.5(1,618)$ & $29.1(2,201)$ & $30.5(2,816)$ \\
\hline$\%$ of Assignments to Company & 23.7 & 47.2 & 64.8 \\
\hline $\begin{array}{l}\% \text { of Assignments to Group that } \\
\text { Includes Patentee }\end{array}$ & 50.3 & 40.6 & 25.2 \\
\hline
\end{tabular}

Notes and Sources: These estimates were computed from the three cross-sectional samples described in the text. The numbers of observations in the respective cells are reported within parentheses. 
TABLE 4

GEOGRAPHIC DISTRIBUTION OF PATENT ATTORNEYS, 1883

\begin{tabular}{lccc}
\hline \hline Region & Number & Percent of Total & $\begin{array}{c}\text { Percent of Attorneys } \\
\text { Outside } \\
\text { Washington, DC }\end{array}$ \\
\hline New England & 90 & 16.6 & 21.6 \\
Middle Atlantic & 195 & 35.9 & 46.9 \\
East North Central & 104 & 19.2 & 25.0 \\
Washington, DC & 127 & 23.4 & - \\
West North Central & 13 & 2.4 & 3.1 \\
South & 7 & 1.3 & 1.7 \\
West & 7 & 1.3 & 1.7 \\
\hline
\end{tabular}

Notes and Sources: U.S. Patent Office, Names and Addresses of Attorneys Practicing Before the United States Patent Office (Washington, DC: Government Printing Office, 1883). All individual listings receive equal weight, including partnerships. The South does not include Washington, DC. 
Table 5

PATENTING RATES AND SHARES OF PATENTS AND POOPULATION, BY REGION AND URBANIZATION

\begin{tabular}{|c|c|c|c|c|c|c|c|c|c|}
\hline & \multicolumn{3}{|c|}{$1870-1871$} & \multicolumn{3}{|c|}{$1890-1891$} & \multicolumn{3}{|c|}{$1910-1911$} \\
\hline & $\begin{array}{c}\text { Patents } \\
\text { Per } \\
\text { Million }\end{array}$ & $\begin{array}{c}\% \text { of } \\
\text { Patents }\end{array}$ & $\begin{array}{c}\% \text { of } \\
\text { Popula- } \\
\text { tion }\end{array}$ & $\begin{array}{c}\text { Patents } \\
\text { Per } \\
\text { Million }\end{array}$ & $\begin{array}{l}\% \text { of } \\
\text { Patents }\end{array}$ & $\begin{array}{c}\% \text { of } \\
\text { Popula- } \\
\text { tion }\end{array}$ & $\begin{array}{c}\text { Patents } \\
\text { Per } \\
\text { Million }\end{array}$ & $\begin{array}{c}\text { \% of } \\
\text { Patents }\end{array}$ & $\begin{array}{c}\% \text { of } \\
\text { Popula- } \\
\text { tion }\end{array}$ \\
\hline \multicolumn{10}{|c|}{ New England } \\
\hline No City & 438.5 & 6.7 & 5.0 & 382.4 & 3.1 & 3.0 & 336.7 & 1.8 & 1.8 \\
\hline 25,000 & $1,039.2$ & 11.0 & 3.4 & 989.9 & 9.4 & 3.4 & 667.2 & 3.9 & 2.0 \\
\hline 100,000 & - & - & - & 870.2 & 1.0 & 0.4 & 552.4 & 4.3 & 2.6 \\
\hline 250,000 & $1,875.9$ & 4.1 & 0.7 & $1,250.1$ & 2.7 & 0.8 & 594.8 & 1.4 & 0.8 \\
\hline TOTAL & 775.8 & 21.8 & 9.1 & 772.0 & 16.2 & 7.6 & 534.3 & 11.4 & 7.2 \\
\hline \multicolumn{10}{|c|}{ Middle Atlantic } \\
\hline No City & 295.6 & 13.0 & 14.3 & 280.6 & 6.7 & 8.7 & 289.7 & 4.9 & 5.7 \\
\hline 25,000 & 603.9 & 3.6 & 1.9 & 681.9 & 6.6 & 3.5 & 409.4 & 5.6 & 4.5 \\
\hline 100,000 & $1,009.0$ & 4.8 & 1.5 & 795.2 & 3.0 & 1.4 & 481.2 & 1.8 & 1.2 \\
\hline 250,000 & $1,137.4$ & 18.7 & 5.3 & 943.5 & 18.0 & 6.9 & 644.0 & 18.6 & 9.6 \\
\hline TOTAL & 563.4 & 40.1 & 23.1 & 607.0 & 34.4 & 20.5 & 488.6 & 30.8 & 21.1 \\
\hline \multicolumn{10}{|c|}{ East North Central } \\
\hline No City & 237.8 & 15.2 & 20.8 & 240.2 & 10.4 & 15.8 & 227.1 & 7.5 & 11.0 \\
\hline 25,000 & 889.8 & 4.2 & 1.5 & 703.8 & 3.6 & 1.9 & 443.0 & 3.9 & 2.9 \\
\hline 100,000 & 724.2 & 3.6 & 1.6 & 763.0 & 2.2 & 1.0 & 789.3 & 2.6 & 1.1 \\
\hline 250,000 & - & - & - & $1,139.4$ & 9.6 & 3.0 & 850.9 & 12.4 & 4.9 \\
\hline TOTAL & 312.2 & 23.0 & 23.9 & 429.9 & 25.8 & 21.7 & 442.3 & 26.4 & 19.9 \\
\hline \multicolumn{10}{|c|}{ West North Central } \\
\hline No City & 129.4 & 3.6 & 9.0 & 168.4 & 5.4 & 11.7 & 194.7 & 5.6 & 9.5 \\
\hline 25,000 & 239.9 & 0.2 & 0.2 & 300.6 & 0.7 & 0.8 & 351.2 & 1.3 & 1.2 \\
\hline 100,000 . & - & - & - & 588.9 & 1.7 & 1.0 & 568.3 & 1.3 & 0.7 \\
\hline 250,000 & 293.3 & 0.8 & 0.9 & 938.4 & 2.0 & 0.8 & 623.8 & 2.3 & 1.2 \\
\hline TOTAL & 146.5 & 4.6 & 10.1 & 248.7 & 9.8 & 14.3 & 272.0 & 10.4 & 12.7 \\
\hline \multicolumn{10}{|l|}{ South } \\
\hline No City & 53.2 & 4.8 & 29.0 & 63.5 & 5.0 & 28.2 & 74.7 & 5.9 & 26.6 \\
\hline 25,000 & 266.4 & 0.9 & 1.1 & 452.5 & 2.3 & 1.8 & 334.0 & 2.7 & 2.7 \\
\hline 100,000 & 563.8 & 1.4 & 0.8 & 434.2 & 0.8 & 0.7 & 310.3 & 1.2 & 1.3 \\
\hline 250,000 & 492.8 & 1.3 & 0.9 & 421.8 & 1.0 & 0.8 & 307.9 & 1.0 & 1.1 \\
\hline TOTAL & 85.8 & 8.4 & 31.9 & 103.1 & 9.0 & 31.5 & 114.4 & 10.8 & 31.7 \\
\hline \multicolumn{10}{|l|}{ West } \\
\hline No City & 263.3 & 1.1 & 1.5 & 265.3 & 2.4 & 3.3 & 283.2 & 3.8 & 4.5 \\
\hline 25,000 & - & - & - & 452.5 & 1.0 & 0.8 & 612.7 & 1.3 & 0.7 \\
\hline 100,000 & 876.4 & 1.1 & 0.4 & - & - & - & 591.1 & 2.1 & 1.2 \\
\hline 250,000 & - & - & - & $1,056.9$ & 1.4 & 0.5 & 977.2 & 2.9 & 1.0 \\
\hline TOTAL & 366.7 & 2.2 & 1.9 & 381.6 & 4.8 & 4.5 & 458.4 & 10.2 & 7.5 \\
\hline
\end{tabular}

Notes and Sources: The estimates were computed from the sample. The observations are classified by geographic area: counties with no city of 25,000 residents or larger; counties with the largest city between 25,000 and 100,000; counties with the largest city between 100,000 and 250,000 ; and counties with more than 250,000 in the largest city. 
TABLE 6

DISTRIBUTION OF PATENTS BY PATENTEE COMMITMENT TO

PATENTING, 1790-1930

\begin{tabular}{|c|c|c|c|c|c|c|}
\hline & \multicolumn{6}{|c|}{ Number of "Career" Patents by Patentee } \\
\hline & $\begin{array}{c}1 \text { Patent } \\
\% \\
\end{array}$ & $\begin{array}{c}2 \text { Patents } \\
\% \\
\end{array}$ & $\begin{array}{c}3 \text { Patents } \\
\% \\
\end{array}$ & $\begin{array}{c}\text { 4-5 Patents } \\
\%\end{array}$ & $\begin{array}{c}\text { 6-9 Patents } \\
\% \\
\end{array}$ & $\begin{array}{c}10+\text { Patents } \\
\%\end{array}$ \\
\hline $1790-1811$ & 51.0 & 19.0 & 12.0 & 7.6 & 7.0 & 3.5 \\
\hline $1812-1829$ & 57.5 & 17.4 & 7.1 & 7.6 & 5.5 & 4.9 \\
\hline $1830-1842$ & 57.4 & 16.5 & 8.1 & 8.0 & 5.6 & 4.4 \\
\hline $1870-1871$ & 21.1 & 12.5 & 9.9 & 15.8 & 11.8 & 28.9 \\
\hline $1890-1891$ & 19.5 & 10.3 & 10.3 & 10.3 & 13.8 & 35.9 \\
\hline $1910-1911$ & 33.2 & 14.3 & 8.2 & 9.8 & 9.4 & 25.0 \\
\hline
\end{tabular}

Sources and Notes: The figures from 1790 to 1842 are drawn from Kenneth L. Sokoloff and B. Zorina

Khan, "The Democratization of Invention During Early Industrialization: Evidence from the United States, 1790-1846," Journal of Economic History, 50 (June 1990), pp. 363-78. The figures for the latter years were computed from a longitudinal data set constructed by selecting all the patentees in the crosssectional samples (see Table 2 for a description) whose family names began with the letter " $B$ " and collecting information on the patents they received during the twenty-five years before and after they appeared in the samples. This data set contains information on 6057 patents granted to the 561 " $\mathrm{B}$ " inventors. 
Table 7

REGRESSIONS WITH THE NUMBER OF PATENTS AWARDED TO THE PATENTEE AS THE DEPENDENT VARIABLE

\begin{tabular}{|c|c|c|c|}
\hline & $1870-71$ & $1890-91$ & $1910-11$ \\
\hline Intercept & $-0.205(0.18)$ & $-1.107(0.19)$ & $-1.030(0.16)$ \\
\hline \multicolumn{4}{|l|}{ Region of Patentee: } \\
\hline New England & $0.114(0.05)$ & $0.165(0.049)$ & $0.180(0.04)$ \\
\hline Mid Atlantic & $0.116(0.04)$ & $0.133(0.04)$ & $0.117(0.03)$ \\
\hline West North Central & $-0.079(0.08)$ & $0.011(0.05)$ & $-0.039(0.04)$ \\
\hline South & $0.027(0.06)$ & $0.037(0.05)$ & $0.029(0.04)$ \\
\hline West & $-0.138(0.11)$ & $-0.175(0.06)$ & $-0.089(0.04)$ \\
\hline Foreign & $0.279(0.20)$ & $1.187(0.19)$ & $1.104(0.16)$ \\
\hline Urban County & $0.033(0.04)$ & $0.168(0.04)$ & $0.128(0.04)$ \\
\hline Metropolitan Center & $0.042(0.04)$ & $-0.008(0.04)$ & $-0.014(0.03)$ \\
\hline Sector: & & & \\
\hline Energy & $0.086(0.05)$ & $0.184(0.05)$ & $0.160(0.05)$ \\
\hline Manufacturing & $0.089(0.04)$ & $0.017(0.05)$ & $0.109(0.04)$ \\
\hline Transportation & $0.019(0.06)$ & $0.147(0.05)$ & $0.144(0.05)$ \\
\hline Construction & $-0.022(0.06)$ & $0.018(0.06)$ & $0.104(0.06)$ \\
\hline Miscellaneous & $0.002(0.08)$ & $-0.132(0.07)$ & $0.019(0.06)$ \\
\hline Patent Assigned & $-0.042(0.05)$ & $0.024(0.04)$ & $0.096(0.04)$ \\
\hline Assigned to Companies & $0.784(0.09)$ & $0.304(0.06)$ & $0.293(0.05)$ \\
\hline Assigned Out of State & $0.608(0.10)$ & $0.161(0.10)$ & $0.015(0.15)$ \\
\hline Assigned to Companies Out of State & $-1.033(0.20)$ & $0.217(0.13)$ & $0.103(0.11)$ \\
\hline Log (Patenting Rate) & $0.058(0.03)$ & $0.188(0.03)$ & $0.161(0.02)$ \\
\hline $\mathrm{N}$ & 1,599 & 2,164 & $2 ; 781$ \\
\hline $\mathbf{R}^{2}$ & 0.13 & 0.16 & 0.14 \\
\hline
\end{tabular}

Notes and Sources: The dependent variable is the log of the number of patents awarded to the patentee in the year in question. The intercept reflects the record of a patentee responsible for an unassigned agriculturalfood processing patent from a rural county in the East North Central region. See the note to Table 10. 
TABLE 8

DESCRIPTIVE STATISTICS ON THE CAREERS OF PATENTEES

IN THE "B" SAMPLE

\begin{tabular}{|c|c|c|c|c|}
\hline & $1870-71$ & $1890-91$ & $1910-11$ & Total \\
\hline & \multicolumn{4}{|c|}{ Means Computed Over Patentees } \\
\hline \multicolumn{5}{|l|}{ Not Assigned at Issue } \\
\hline Ave. No. of Patents & 8.0 & 10.0 & 6.4 & 7.9 \\
\hline Length of Career (Yrs.) & 13.2 & 14.7 & 11.1 & 12.7 \\
\hline Career Assign. Rate (\%) & 8.3 & 11.5 & 9.2 & 9.6 \\
\hline Number of Patentees & 121 & 117 & 178 & 416 \\
\hline Percent of All Patentees & 84.6 & 63.9 & 75.7 & 74.2 \\
\hline \multicolumn{5}{|l|}{ Share Assignment } \\
\hline Ave. No. of Patents & 5.4 & 11.1 & 2.6 & 6.9 \\
\hline Length of Career (Yrs.) & 10.6 & 13.5 & 8.1 & 11.0 \\
\hline Career Assign. Rate (\%) & 67.1 & 75.3 & 87.5 & 76.7 \\
\hline Number of Patentees & 13 & 19 & 14 & 46 \\
\hline Percent of All Patentees & 9.1 & 10.4 & 6.0 & 8.2 \\
\hline \multicolumn{5}{|l|}{ Full Assign. to Individual } \\
\hline Ave. No. of Patents & 5.3 & 29.0 & 3.0 & 12.1 \\
\hline Length of Career (Yrs.) & 12.0 & 18.3 & 5.3 & 11.9 \\
\hline Career Assign. Rate (\%) & 52.1 & 74.1 & 76.4 & 66.7 \\
\hline Number of Patentees & 7 & 6 & 6 & 19 \\
\hline Percent of All Patentees & 4.9 & 3.3 & 2.6 & 3.4 \\
\hline \multicolumn{5}{|l|}{ Full Assign. to Company } \\
\hline Ave. No. of Patents & 30.0 & 23.7 & 32.6 & 28.0 \\
\hline Length of Career (Yrs.) & 25.5 & 21.7 & 23.5 & 22.6 \\
\hline Career Assign. Rate (\%) & 62.1 & 70.7 & 80.9 & 75.2 \\
\hline Number of Patentees & 2 & 41 & 37 & 80 \\
\hline Percent of All Patentees & 1.4 & 22.4 & 15.7 & 14.3 \\
\hline
\end{tabular}


TABLE 8 cont.

DESCRIPTIVE STATISTICS ON THE CAREERS OF PATENTEES

IN THE "B" SAMPLE

\section{$1870-71$}

1890-91

1910-11

Total

Means Computed Over Patents

Not Assigned at Issue

Ave. No. of Patents

Length of Career (Yrs.)

Career Assign. Rate (\%)

Number of Patents

Percent of All Patents

\begin{tabular}{rrrr}
\hline & & & \\
20.0 & 39.7 & 38.2 & 33.7 \\
21.5 & 28.2 & 26.0 & 25.6 \\
14.2 & 23.5 & 22.0 & 20.4 \\
900 & 1264 & 1053 & 3217 \\
80.0 & 50.1 & 43.8 & 53.1
\end{tabular}

Share Assignment

Ave. No. of Patents

Length of Career (Yrs.)

19.3

40.5

24.4

30.7

20.7

27.5

25.6

25.4

Career Assign. Rate (\%)

39.9

Number of Patents

66.5

156

62.8

59.4

75

108

339

Percent of All Patents

6.6

6.2

4.5

5.6

Full Assign. to Individual

Ave. No. of Patents

Length of Career (Yrs.)

27.3

76.5

39.2

58.6

26.1

30.6

28.3

29.2

40.3

77.0

70.9

67.9

Number of Patents

82

224

74

381

Percent of All Patents

7.3

8.9

3.1

6.2

Full Assign. to Company

Ave. No. of Patents

35.9

62.5

32.9

78.0

135.6

101.8

Length of Career (Yrs.)

26.6

880

35.1

33.9

53.3

85.5

81.3

Number of Patents

73

34.9

1168

2121

Percent of All Patents

6.5

48.6

35.0 
TABLE 9

REGRESSIONS WITH CAREER TOTAL OF PATENTS AND LENGTH OF CAREER AS THE DEPENDENT VARIABLES

\begin{tabular}{|c|c|c|c|c|c|c|}
\hline & \multicolumn{3}{|c|}{$\begin{array}{l}\text { Log of Number of } \\
\text { Career Patents }\end{array}$} & \multicolumn{3}{|c|}{$\begin{array}{c}\text { Log of Years from First to } \\
\text { Last Patent Plus One }\end{array}$} \\
\hline & (1) & $(2)$ & (3) & (4) & $(5)$ & (6) \\
\hline Constant & $\begin{array}{l}2.311 \\
(0.05)\end{array}$ & $\begin{array}{r}2.274 \\
(0.04)\end{array}$ & $\begin{array}{l}2.267 \\
(0.04)\end{array}$ & $\begin{array}{r}2.824 \\
(0.03)\end{array}$ & $\begin{array}{l}2.811 \\
(0.03)\end{array}$ & $\begin{array}{l}2.808 \\
(0.03)\end{array}$ \\
\hline $\begin{array}{l}\text { Prop. of Career Patents } \\
\text { Assigned Fully to } \\
\text { Individuals at Issue }\end{array}$ & $\begin{array}{r}0.370 \\
(0.11)\end{array}$ & $\begin{array}{r}1.027 \\
(0.10)\end{array}$ & $\begin{array}{r}0.957 \\
(0.10)\end{array}$ & $\begin{array}{r}0.111 \\
(0.07)\end{array}$ & $\begin{array}{r}0.326 \\
(0.07)\end{array}$ & $\begin{array}{r}0.301 \\
(0.07)\end{array}$ \\
\hline $\begin{array}{l}\text { Prop. Assigned Fully to } \\
\text { Companies at Issue }\end{array}$ & & $\begin{array}{r}1.854 \\
(0.04)\end{array}$ & $\begin{array}{r}1.774 \\
(0.06)\end{array}$ & & $\begin{array}{r}0.605 \\
(0.03)\end{array}$ & $\begin{array}{l}0.605 \\
(0.04)\end{array}$ \\
\hline \multicolumn{7}{|l|}{$\begin{array}{l}\text { Interaction with Year } \\
\text { of Sampling: }\end{array}$} \\
\hline $1890-91$ & & & $\begin{array}{r}-0.198 \\
(0.05)\end{array}$ & & & $\begin{array}{r}-0.097 \\
(0.04)\end{array}$ \\
\hline $1910-11$ & & & $\begin{array}{r}0.283 \\
(0.06)\end{array}$ & & & $\begin{array}{r}-0.068 \\
(0.04)\end{array}$ \\
\hline \multicolumn{7}{|l|}{ Region of Patentee: } \\
\hline New England & $\begin{array}{r}0.187 \\
(0.04)\end{array}$ & $\begin{array}{r}-0.120 \\
(0.04)\end{array}$ & $\begin{array}{r}-0.077 \\
(0.04)\end{array}$ & $\begin{array}{r}0.106 \\
(0.03)\end{array}$ & $\begin{array}{r}0.006 \\
(0.03)\end{array}$ & $\begin{array}{r}0.021 \\
(0.03)\end{array}$ \\
\hline Middle West & $\begin{array}{r}0.244 \\
(0.04)\end{array}$ & $\begin{array}{r}0.303 \\
(0.03)\end{array}$ & $\begin{array}{r}0.306 \\
(0.03)\end{array}$ & $\begin{array}{r}-0.090 \\
(0.02)\end{array}$ & $\begin{array}{r}-0.070 \\
(0.02)\end{array}$ & $\begin{array}{r}-0.070 \\
(0.02)\end{array}$ \\
\hline South & $\begin{array}{r}-0.293 \\
(0.07)\end{array}$ & $\begin{array}{r}-0.104 \\
(0.06)\end{array}$ & $\begin{array}{r}-0.079 \\
(0.06)\end{array}$ & $\begin{array}{r}-0.111 \\
(0.04)\end{array}$ & $\begin{array}{r}-0.049 \\
(0.04)\end{array}$ & $\begin{array}{r}-0.040 \\
(0.04)\end{array}$ \\
\hline West & $\begin{array}{r}-1.501 \\
(0.09)\end{array}$ & $\begin{array}{r}-0.961 \\
(0.08)\end{array}$ & $\begin{array}{r}-0.916 \\
(0.08)\end{array}$ & $\begin{array}{r}-0.731 \\
(0.06)\end{array}$ & $\begin{array}{r}-0.554 \\
(0.06)\end{array}$ & $\begin{array}{r}-0.540 \\
(0.06)\end{array}$ \\
\hline Foreign & $\begin{array}{r}-0.676 \\
(0.09)\end{array}$ & $\begin{array}{r}-0.533 \\
(0.07)\end{array}$ & $\begin{array}{r}-0.529 \\
(0.07)\end{array}$ & $\begin{array}{r}-0.380 \\
(0.05)\end{array}$ & $\begin{array}{r}-0.332 \\
(0.05)\end{array}$ & $\begin{array}{r}-0.333 \\
(0.05)\end{array}$ \\
\hline
\end{tabular}




\begin{tabular}{lrrr|rrr} 
Urban County & 0.106 & 0.144 & 0.154 & 0.020 & 0.031 & 0.034 \\
& $(0.05)$ & $(0.04)$ & $(0.04)$ & $(0.03)$ & $(0.03)$ & $(0.03)$ \\
Metropolitan Center & 0.474 & 0.238 & 0.227 & 0.147 & 0.070 & 0.067 \\
& $(0.05)$ & $(0.04)$ & $(0.04)$ & $(0.03)$ & $(0.03)$ & $(0.03)$ \\
& & & & & & \\
Sampled in 1890-91 & 0.739 & 0.197 & 0.293 & 0.370 & 0.193 & 0.228 \\
& $(0.04)$ & $(0.04)$ & $(0.04)$ & $(0.03)$ & $(0.03)$ & $(0.03)$ \\
Sampled in 1910-11 & 0.835 & 0.046 & -0.056 & 0.375 & 0.118 & 0.085 \\
& $(0.05)$ & $(0.04)$ & $(0.05)$ & $(0.04)$ & $(0.03)$ & $(0.03)$ \\
$\mathrm{N}$ & 6057 & 6057 & 6057 & 6057 & 6057 & 6057 \\
$\mathrm{R}^{2}$ & & & & & & \\
& 0.19 & 0.38 & 0.39 & 0.08 & 0.14 & 0.15 \\
\hline
\end{tabular}

Notes and Sources: These regressions were estimated over all of the individual patent observations contained in our "B" sample. This sample was collected by gathering information on all of the patents filed over fifty years by 561 patentees randomly drawn from cross-sections for 1870-71, 1890-91, and 1910-11. The variables pertaining to behavior over the careers of the patentees were calculated from the fifty-year totals for the respective inventors. The constant refers to a patent received by a resident of a county in the Middle Atlantic without a city of 25,000 or more inhabitants. Urban counties had cities of greater than 25,000, and metropolitan centers had cities of greater than 100,000. This patentee was sampled from the 1870-71 cross-section, and his record of patenting was compiled by searching the previous twenty-five years and the next twenty-five years. The regression coefficients are reported with standard errors in parentheses. 
TABLE 10

DESCRIPTIVE STATISTICS ON PATENT ASSIGNMENT, BY CORRESPONDENT TYPE, 1871-1911

\begin{tabular}{|c|c|c|c|c|c|}
\hline 1871 & & $\begin{array}{l}\text { Registered } \\
\text { Patent } \\
\text { Agent } \\
\end{array}$ & $\begin{array}{l}\text { Patentee, } \\
\text { Assignor, } \\
\text { or } \\
\text { Assignee }\end{array}$ & $\begin{array}{c}\text { Third } \\
\text { Party but } \\
\text { not } \\
\text { Registered } \\
\end{array}$ & Unknown \\
\hline \multirow[t]{2}{*}{ Number } & Patents & 114 & 144 & 126 & 53 \\
\hline & Contracts & 85 & 98 & 82 & 21 \\
\hline \multirow[t]{2}{*}{$\%$ of Total Number } & Patents & 26.1 & 33.0 & 28.8 & 12.1 \\
\hline & Contracts & 29.7 & 33.9 & 29.4 & 7.0 \\
\hline Proportion Assigned & Patents & 0.47 & 0.09 & 0.18 & - \\
\hline Before Issue & Contracts & 0.61 & 0.08 & 0.23 & - \\
\hline Proportion Secondary & Patents & 0.35 & 0.33 & 0.32 & 0.85 \\
\hline Assignments & Contracts & 0.20 & 0.31 & 0.30 & 0.80 \\
\hline Proportion National & Patents & 0.89 & 0.53 & 0.71 & - \\
\hline Assignments & Contracts & 0.89 & 0.51 & 0.70 & - \\
\hline Proportion Assigned & Patents & 0.28 & 0.24 & 0.20 & 0.66 \\
\hline to Company & Contracts & 0.25 & 0.16 & 0.20 & 0.48 \\
\hline Prop. Where Patentee & Patents & 0.46 & 0.28 & 0.40 & 0.32 \\
\hline $\begin{array}{l}\text { in County With } \\
\text { City of }>100,000\end{array}$ & Contracts & 0.39 & 0.31 & 0.35 & 0.38 \\
\hline Patentees' Ave. 5-Yr. & Patents & 3.90 & 3.73 & 3.35 & 4.69 \\
\hline Total of Patents & Contracts & 2.45 & 3.10 & 3.27 & 3.05 \\
\hline Patentees' Ave. 5-Yr. & Patents & 1.47 & 0.88 & 0.80 & 0.88 \\
\hline $\begin{array}{l}\text { Total of Patents } \\
\text { Assigned at Issue }\end{array}$ & Contracts & 1.08 & 0.64 & 0.88 & 0.70 \\
\hline $\begin{array}{l}\text { Ave. No. of Contracts } \\
\text { Assigned by } \\
\text { Correspondent }\end{array}$ & Contracts & 2.36 & 1.05 & 1.26 & - \\
\hline
\end{tabular}


TABLE 10 cont.

DESCRIPTIVE STATISTICS ON PATENT ASSIGNMENT, BY CORRESPONDENT TYPE, 1871-1911

\begin{tabular}{|c|c|c|c|c|c|}
\hline 1891 & & $\begin{array}{l}\text { Registered } \\
\text { Patent } \\
\text { Agent } \\
\end{array}$ & $\begin{array}{l}\text { Patentee, } \\
\text { Assignor, } \\
\text { or } \\
\text { Assignee }\end{array}$ & $\begin{array}{c}\text { Third } \\
\text { Party but } \\
\text { not } \\
\text { Registered }\end{array}$ & Unknown \\
\hline \multirow[t]{2}{*}{ Number } & Patents & 336 & 188 & 235 & 69 \\
\hline & Contracts & 219 & 89 & 88 & 27 \\
\hline \multirow[t]{2}{*}{$\%$ of Total Number } & Patents & 42.7 & 21.9 & 27.4 & 8.0 \\
\hline & Contracts & 51.8 & 21.0 & 20.8 & 6.4 \\
\hline Proportion Assigned & Patents & 0.44 & 0.15 & 0.32 & 0.24 \\
\hline Before Issue & Contracts & 0.52 & 0.18 & 0.40 & 0.37 \\
\hline Proportion Secondary & Patents & 0.20 & 0.31 & 0.37 & 0.81 \\
\hline Assignments & Contracts & 0.13 & 0.25 & 0.23 & 0.78 \\
\hline Proportion National & Patents & 0.91 & 0.78 & 0.86 & - \\
\hline Assignments & Contracts & 0.94 & 0.72 & 0.78 & - \\
\hline Proportion Assigned & Patents & 0.39 & 0.28 & 0.48 & 0.68 \\
\hline to Company & Contracts & 0.41 & 0.27 & 0.45 & 0.52 \\
\hline Prop. Where Patentee & Patents & 0.51 & 0.45 & 0.55 & 0.58 \\
\hline $\begin{array}{l}\text { in County With } \\
\text { City of }>100,000\end{array}$ & Contracts & 0.46 & 0.45 & 0.48 & 0.52 \\
\hline Patentees' Ave. 5-Yr. & Patents & 6.61 & 3.65 & 5.80 & 5.45 \\
\hline Total of Patents & Contracts & 4.90 & 3.43 & 5.17 & 3.00 \\
\hline Patentees' Ave. 5-Yr. & Patents & 4.29 & 1.10 & 3.50 & 3.65 \\
\hline $\begin{array}{l}\text { Total of Patents } \\
\text { Assigned at Issue }\end{array}$ & Contracts & 3.39 & 1.27 & 3.43 & 1.74 \\
\hline $\begin{array}{c}\text { Ave. No. of Contracts } \\
\text { Assigned by } \\
\text { Correspondent }\end{array}$ & Contracts & 1.77 & 1.07 & 1.24 & - \\
\hline
\end{tabular}


includes information on all such patent assignments filed with the Patent Office during the months of January through March for 1871, 1891, and 1911. Because some contracts involved the sale or transfer of more than one patent, and some encompassed multiple transfers of the same patent (such as the sale of a patent from $A$ to $B$, and then another transfer of the patent from $B$ to $C$ ), we report one set of figures computed over all patents assigned and another set computed over all contracts. For every patent in our sample of assignments, we compiled a five-year record of all of the patents received by the patentee, using the year of the assigned patent as the central year. From this record, we computed the total number of patents the patentee received over the five years and the total number of these patents that he assigned at issue. We categorized each assignment contract (and the patents it included) by the identity of the person to whom all correspondence about the assignments was to be addressed. Working with lists of patent agents and lawyers from 1883 and 1905, we distinguished correspondents who were formally registered with the Patent Office in at least one of these two years as a separate class of intermediaries. Correspondents who were principals to the contract (either the patentee, the assignor, or the assignee of one of the patents involved) were grouped together in a second category of intermediaries. A third category consisted of third parties who did not appear on either of the two lists of registered agents that we relied upon. It seems likely, however, that we would have been able to identify some of these correspondents as registered agents if we had rosters for additional years. Finally, we include an "unknown" category that is primarily composed of cases where multiple patents were assigned together and where the details of the contract were summarized in the record of another patentee whose family name began with a letter other than " $\mathrm{B}$ "and was thus in another Digest volume. 